\title{
Legitimidad política y organización social en las comunidades indígenas de la provincia de Chayanta (siglo XVIII)*
}

Sergio Serulnikov

Boston College

\begin{abstract}
El artículo explora la relación entre las jerarquías comunales de autoridad, la estructuración étnica y los criterios de legitimidad política en la provincia altoperuana de Chayanta durante el siglo XVIII. Se postula que la crisis de autoridad cacical que desembocaría en la sublevación de 1780 radicó en que la institución continuó jugando un papel primordial en la reproducción social andina -un papel que no podía ser suprimido de no mediar cambios drásticos en las tradicionales formas de verticalidad ecológica y en los modos de distribución de los recursos y obligaciones materiales entre los miembros de los ayllus-, al tiempo que su legitimidad dejó de estar sometida a rígidos principios nobiliarios. Las protestas campesinas afectaron tanto a los caciques "interinos" como a los hereditarios y estuvieron orientadas a cerrar la brecha entre la racionalidad económica y la racionalidad política de los jefes étnicos. El trabajo procura situar estos desarrollos en el contexto general del área andina.
\end{abstract}

PALABRAS ClaVE: caciques andinos, provincia de Chayanta, repartimientos, doctrinas de indios, legitimidad política, reciprocidad, rebelión pan-andina de 1780-1781

This article explores the relationship between the indigenous hierarchies of government, the ethnic organization, and the shifting notions of political legitimacy in the Upper Peruvian province of Chayanta during the eighteenth century. It argues that the crisis of Andean chieftainships resulting in the 1780 insurrection was originated in that the caciques continued to play a central role in the functioning of the rural society - a role that could not be diminished unless drastic changes in the ayllus' traditional patterns of ecological verticality and distribution of economic resources among their members occurred-, at the same time that that their ideological legitimacy was no longer subjected to somewhat rigid aristocratic principles. Peasant protests affected interim and hereditary caciques alike and tried to bridge the gap between the economic and political rationality of the communities' authorities. The work seeks to locate these developments within the general context of the Andean area.

KEYwORDS: Andean chiefs, province of Chayanta, Indian districts, Indian parishes, political legitimacy, reciprocity, pan-Andean insurrection of 1780-1781

* Una versión preliminar de este estudio fue presentada en el $51^{\circ}$ Congreso Internacional de Americanistas, simposio "Autoridades en los Andes. Status, Poder, Genealogía y Cambios Políticos, siglos XVI-XVIII", Santiago, Chile, 14-18 de julio de 2003. Agradezco sus comentarios a Mercedes del Río, Ana María Presta y a los participantes en el simposio. 
La importancia de los caciques andinos en el funcionamiento del régimen colonial ha sido resaltada unánimemente en la literatura histórica. Intermediarios claves entre las comunidades rurales y el estado, el rol de los caciques fue el resultado de la confluencia de las estructuras políticas andinas y europeas. Tras la conquista del Tawantinsuyu, la Corona española reconoció la autonomía política de los pueblos nativos y permitió la formación de una aristocracia de "señores naturales". En varias zonas de los Andes, las familias nobles indígenas, muchas de la cuales podían llevar sus orígenes a los tiempos del incanato, conservaron su autoridad y prestigio social hasta finales del siglo XVIII. Pero aún en las regiones donde los antiguos linajes prehispánicos fueron desapareciendo o perdieron su status a lo largo del período colonial, los jefes étnicos continuaron detentando considerable poder. Bajo el sistema de gobierno indirecto consolidado desde el siglo XVI, recayó en los caciques la responsabilidad de la recaudación tributaria y el despacho de la cuota de mitayos, las principales fuentes de ingresos fiscales y trabajadores para la industria minera potosina, respectivamente. Por otro lado, las obligaciones monetarias de las comunidades los movieron a integrar economías basadas en ideales de reciprocidad y autosuficiencia en los circuitos mercantiles coloniales. Los estudios monográficos indican que los caciques estuvieron por lo general a cargo de la comercialización de los excedentes agrícolas, la fuerza de transporte y la mano de obra indígena. De su éxito para mediar con el mundo exterior dependía en buena medida la supervivencia de la comunidad rural andina. ${ }^{1}$

No cabe duda que las exacciones coloniales - la mita, los servicios al clero, los tributos, los repartos forzosos de mercancías-, así como las oportunidades de enriquecimiento personal y ascenso social creadas por la economía mercantil y la expansión de los centros urbanos, impusieron formidables presiones sobre la función del cacicazgo en la sociedad andi-

1 Véase, por ejemplo, Barragán Romano, Rosanda: "En torno al modelo comunal mercantil: el caso de Mizque (Cochabamba) en el siglo XVII", 15, Revista Chungara, Arica, 1985; Choque Canqui, Roberto: Sociedad y economía colonial en el sur andino, HISBOL, La Paz, 1993; Glave, Luis Miguel: Trajinantes. Caminos indígenas en la sociedad colonial, siglos XVI/XVII, Instituto de Apoyo Agrario, Lima, 1989, págs. 279-304; Larson, Brooke: "Caciques, Class Structure and the Colonial State", Nova Americana, Turín, 2, 1979; Pease, Franklin: Curacas, reciprocidad y riqueza, Pontificia Universidad Católica del Perú, Lima, 1992; Rivera Cusicanqui, Silvia: "El mallku y la sociedad colonial en el siglo XVII: el caso de J. de Machaca", 1, Avances, La Paz, 1978, págs. 7-27; Saignes, Thierry: "De la borrachera al retrato: los caciques de Charcas entre dos legitimidades", Revista Andina, 5, Cusco, 1987, págs. 139-170. 
na. Este proceso trajo aparejadas profundas modificaciones en las pautas de comportamiento de los jefes étnicos, muchos de los cuales se convirtieron en hacendados y comerciantes de granos, coca, vino, mulas y otros productos agropecuarios, establecieron redes de cooperación y parentesco con sectores hispanos y adoptaron estilos de vida y modelos culturales europeos. Menos evidente es el impacto de estas transformaciones sobre los criterios de legitimidad política. La historiografía ha tendido a desmentir interpretaciones esencialistas basadas en el presupuesto de que el nivel de consenso de las autoridades comunales era proporcional al grado de apego a principios andinos precolombinos de comportamiento. En contraposición con enfoques analíticos que establecen el sentido de las instituciones sociales con criterios externos a los de los propios actores, tendemos a pensar hoy que la acumulación económica individual, la observancia de rituales y creencias religiosas católicas o el manejo de la escritura y el idioma español no eran elementos que trazaban por si mismos la línea que separaba a los caciques legítimos de los caciques despóticos.

Dado que el significado de las prácticas estaba determinado por el contexto social, más bien que por las prácticas mismas, el análisis del cacicazgo andino colonial descansa menos en la construcción de modelos abstractos que en estudios de casos locales y sólo la integración de estos puede permitirnos establecer periodizaciones globales. El presente artículo intenta contribuir a esta tarea. Su propósito es trazar la evolución de las jerarquías indígenas de gobierno en la provincia colonial de Chayanta, una zona que se corresponde con el norte de Potosí actual, durante el último siglo de dominio español. La relevancia histórica de esta problemática es bien conocida: fueron los conflictos en torno al control de los cacicazgos los que tornaron esta área en uno de los principales escenarios del masivo levantamiento indígena de 1780-1781. La primera sección explora la articulación entre la estructuración étnica y los sistemas de autoridad de las comunidades indígenas. Examinamos luego las mutaciones en los criterios de legitimidad de los caciques. A modo de conclusión, se plantean algunas reflexiones de carácter general sobre el impacto de estos desarrollos en la historia ulterior de los pueblos norpotosinos. Aunque centrado en Chayanta, el texto procura esbozar ciertos marcos comparativos que nos ayuden a comprender las tendencias comunes a los Andes, así como la especificidad de los procesos de cambio en esta región. 


\section{Autoridad étnica y organización social}

La provincia colonial de Chayanta estaba poblada por varios grupos étnicos cuyos orígenes se remontaban en muchos casos a formaciones precolombinas. Abarcaba aproximadamente el territorio de cuatro grupos - Sacaca, Macha, Pocoata y Chayanta - que habían pertenecido a las confederaciones aymaras Charka y Karakara. ${ }^{2}$ Hacia fines del siglo XVI, tras las reformas implementadas por el virrey Francisco de Toledo y la supresión del régimen de encomiendas en el Perú, la provincia comenzó a adquirir la configuración institucional que perduraría hasta finales de la dominación española. Al igual que en el resto de los Andes, los grupos nativos fueron agrupados, con fines fundamentalmente fiscales y administrativos, en unidades llamadas repartimientos. En el caso de Chayanta, estos repartimientos presentan grandes variaciones tanto en relación a su composición étnica como al grado de continuidad con las sociedades precolombinas. Así, existe cierta correlación histórica entre los repartimientos de Sacaca, Pocoata y Macha y los antiguos señoríos aymaras homónimos. ${ }^{3}$ Sin embargo, el repartimiento de Chayanta agru-

2 Debido en parte a la peculiar dinámica de la conquista en esta región, los grupos que componían las confederaciones Charka y Karakara lograron en términos generales, según resumió Thierry Saignes, "conseguir una división en repartimientos y corregimientos que respetara en gran parte la territorialidad étnica..." Saignes: "De la borrachera"..., pág. 142. Tristan Platt sostiene que "los indios de Macha, Pocoata, Aymaya, Chayanta y Sacaca fueron distribuidos en pueblos, tanto en la puna como en el valle, manteniendo su afiliación étnica precolombina", Platt, Tristan Estado boliviano y ayllu andino. Tierra y tributo en el norte de Potosí, IEP, Lima, pag. 26. Véase también, Bouysse Cassagne, Therese: La identidad Aymara: una aproximación histórica. Hisbol-IFEA, La Paz, 1987; Del Río, Mercedes, "Estructuración étnica Qharaqhara y su desarticulación colonial", en Presta, Ana María:(editora): Espacios, etnias, frontera. Atenuaciones políticas en el sur del Tawantinsuyu, siglos $X V$-XVIII, Ediciones Asur, Sucre, 1995, págs. 35-73; y Platt, Tristan: "Pensamiento político Aymara", en Xavier Albó (comp.): Raíces de América: el mundo Aymara, Alianza Editorial, Madrid, 1988, págs. 365-450.

3 Esto no quiere decir por cierto que exista una completa continuidad en los territorios étnicos. Thierry Saignes observa, por ejemplo, que la cabecera étnica de Macha perdió el acceso a valles lejanos pero conservó la posesión de los valles aledaños (San Marcos de Miraflores, Carasi y otros valles cercanos a sus territorios de puna) Saignes, Thierry: "Lobos y ovejas. Formación y desarrollo de los pueblos y comunidades en el sur andino (Siglos XVI-XX)", en Moreno Yáñez, y Salomon, Frank (editores): Reproducción y transformación de las sociedades andinas, Ediciones ABYA-YALA, Quito, 1991, pág. 116]. El control territorial de los indios se vio asimismo afectado por la expansión de las haciendas en las áreas de valle, un proceso que se consolidó en Chayanta durante la privatización de tierras comunales llevada a cabo por el revisitador Joseph de la Vega Alvarado en 1645. Del mismo modo, la acumulación de parcelas en manos de las familias "principales" de las respectivas comunidades, y las relaciones de parentesco entre estas familias y los vecinos hispanos y mestizos de 
paba para el siglo XVIII a seis grupos étnicos (Laymi, Chullpa, Puraca, Chayantaca, Sicoya y Caracha) que, aunque pudieron formar parte en el pasado de la jefatura prehispánica del mismo nombre, se transformaron luego de la conquista en comunidades autónomas. Esto significa que mientras los términos "Sacaca", "Pocoata" o "Macha" designaban tanto repartimientos como entidades políticas reales —comunidades dispersas y multiecológicas compuestas de alrededor de diez ayllus menores distribuidos en las parcialidades de Anansaya o Urinsaya-, "Chayanta" sólo denotaba una unidad administrativa estatal (además naturalmente del nombre de la provincia). La disrupción causada por la reorganización colonial se manifiesta asimismo en que no existían autoridades étnicas a nivel de las parcialidades y que sólo Sicoya, Laymi y Chullpa mantuvieron una división en ayllus menores. Por otro lado, Aymaya (un grupo que durante las reformas toledanas fue agrupado junto con Pocoata en el repartimiento de Macha), Jukumani y Panacachi pasaron a conformar dos repartimientos independientes (ver cuadro). ${ }^{4}$ Las comunidades de los repartimientos de Moscari y San Pedro de Buena Vista tuvieron, por último, orígenes diferentes a los del resto pues surgieron durante el período colonial como fruto del agrupamiento de familias integrantes de algunas de las formaciones precolombinas. Además, en contraste con los otros repartimientos, los grupos Auquimarca y Cayana (San Pedro de Buena Vista) y Moscari ocupaban, respectivamente, territorios contiguos en el valle y en una zona ecológica intermedia entre la puna y las tierras bajas (taypirana).

\footnotetext{
los pueblos rurales, redujo de hecho los territorios étnicos. Por ejemplo, durante la década de 1770, se dijo de las familias nobles de Pocoata, "la demasía de tierras que poseen, porque todo el tiempo que estuvieron entendiendo en la recaudación de tributos se hicieron para si y para todos sus parientes de lo más florido de las tierras de comunidad. De tal manera que se juzga cada uno como hacendado y dispone de ellas a su voluntad" [Archivo Nacional de Bolivia (ANB), Expedientes Coloniales (EC), 1776, 12, ff. 28-19v). En referencia a una prolongada disputa en torno a la herencia de tierras comunales en el valle de San Pedro de Buena Vista entre dos descendientes de caciques del grupo Chayantaca (una de los cuales se había casado con un hacendado español), un funcionario de la Audiencia sostuvo que como consecuencia de la política de los corregidores de validar las privatizaciones "resultan con el tiempo pleitos que los mestizos arman contra la comunidad decreciendo con esto las dotes que tienen para mantener sus cargas y Reales Tributos" [ANB, Tierras e Indios (TI), 1772,118 , ff. 14-15v].

4 Sobre la relación entre Macha, Pocoata y Aymaya, véase Del Río: "Estructuración étnica...", págs, 12-15; y Platt, Tristan: "Mapas coloniales de la provincia de Chayanta: dos visiones conflictivas de un solo paisaje", en Homenaje a Gunnar Mendoza, La Paz, 1978, págs. 102-103; y "Pensamiento político...”, pág. 419.
} 
PRINCIPALES REPARTIMIENTOS DE LA PROVINCIA DE CHAYANTA (SIGLO XVIII)

\begin{tabular}{|c|c|c|c|c|c|c|c|c|}
\hline \multirow[b]{2}{*}{ Repartimientos } & \multicolumn{8}{|c|}{ Districtos de Valle (Doctrinas) } \\
\hline & $\begin{array}{l}\text { Grupos } \\
\text { Étnicos }\end{array}$ & $\begin{array}{c}\text { San Pedro de } \\
\text { Buena Vista }\end{array}$ & Carasi & Micani & $\begin{array}{l}\text { San Marcos } \\
\text { de Miraflores }\end{array}$ & Acasio & Parica & $\begin{array}{c}\text { Tributarios } \\
(1772)^{*}\end{array}$ \\
\hline Pocoata & Pocoata & & $\mathrm{X}$ & $X$ & & & & 577 \\
\hline Macha & Macha & & $\mathrm{X}$ & & $\mathrm{X}$ & & & 587 \\
\hline Sacaca & Sacaca & & & & & $\mathrm{X}$ & & 707 \\
\hline \multirow[t]{6}{*}{ Chayanta } & Laymi & & $X$ & $\mathrm{X}$ & & & & \\
\hline & Puraca & & $\mathrm{X}$ & & & & & \\
\hline & Chullpa & & & $\mathrm{X}$ & & & & \\
\hline & Chayantaca & $X$ & & & & & & \\
\hline & Caracha & & & $X$ & & & & \\
\hline & Sicoya & $X$ & & & & & & 1823 \\
\hline \multirow[t]{2}{*}{ Aymaya } & Aymaya & & & $X$ & & & & \\
\hline & Jukumani & & & $X$ & & & & 445 \\
\hline Panacachi & Panacachi & & & & & & $\mathrm{X}$ & 235 \\
\hline San Pedro de & & & & & & & & \\
\hline \multirow[t]{2}{*}{ Buena Vista** } & Auquimarca & $\mathrm{X}$ & & & & & & \\
\hline & Cayana & $X$ & & & & & & 229 \\
\hline Moscari & Moscari & $\mathrm{X}$ & & & & & & 451 \\
\hline Total & & & & & & & & 5054 \\
\hline
\end{tabular}

*AGN, Sala XIII, 23-3-1, Primer Cuaderno

**Repartimiento de valle

El sistema de cacicazgos en la provincia de Chayanta presenta hacia el siglo XVIII dos características fundamentales. La primera es que los jefes indígenas a diferentes niveles de la organización comunal (ayllu, parcialidad o etnías) siguieron teniendo para esta época un lugar esencial en la reproducción social andina. Caciques, segundas personas (asistentes de los caciques) e hilacatas (cobradores de tributos) continuaron ejerciendo una influencia decisiva en la articulación de los ayllus con el mundo exterior - el estado colonial, los grupos locales de poder, los circuitos mercantiles y las comunidades indígenas vecinas. ${ }^{5}$ Lo hicieron a través de una serie de prácticas tales como la recaudación tributaria conforme a normas culturales propiamente andinas que supeditaban el monto de las

5 En las fuentes del siglo XVIII, los términos de hilacatas y segundas personas designan a menudo autoridades a nivel de los ayllus menores. 
tasas al tipo de parcelas en punas y valles usufructuadas por las familias; la elección de los trabajadores mitayos, los pasantes de las fiestas religiosas y los asistentes de los curas en función de un sistema integrado de turnos; la comercialización de los excedentes agrarios, en particular aquellos producidos en las tierras cultivadas colectivamente (comunes); el arrendamiento de parcelas y molinos de la comunidad; la mediación en el reparto de mercancías de los corregidores; la defensa de la integridad territorial de los ayllus en los cada vez más frecuentes conflictos sobre límites; y la asignación de predios de acuerdo a una combinación de criterios demográficos (tamaño de las familias), sociales (patrocinio de fiestas) y agrarios (disponibilidad de tierras). La acción simbólica constituyó también un atributo central del cargo. Aunque la documentación del período es naturalmente parca con respecto a la vida ritual indígena, sabemos que durante las celebraciones católicas y otras reuniones comunales se esperaba que los caciques llevaran a cabo formas institucionalizadas de generosidad. Así pues, la jerarquía caciquil estaba intrínsecamente asociada a un conjunto de funciones sociales que excedían en mucho la de meros agentes de la Corona y corregidores provinciales. Este no fue por cierto el caso en toda el área andina: en la región de Quito, por ejemplo, Karen Powers ha observado que ya desde fines del siglo XVII el sistema estuvo caracterizado "por su total abandono de cualquier expectativa andina de buen gobierno y por el desdeño de los intereses de las comunidades"; 6 en el pueblo de Andagua, Arequipa, los líderes de redes sociales organizadas alrededor del culto a los antepasados y el comercio regional asumieron las funciones tradicionalmente asociadas a los caciques, quienes comenzaron a ser percibidos como funcionarios

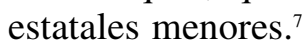

Es posible que una jerarquía paralela de autoridad, los Cabildos indígenas y los puestos en las cofradías, hubiera en parte limitado la autoridad de los señores étnicos norpotosinos. Durante el período colonial, en cada uno de los pueblos de puna y valle se creó un Cabildo indígena conformado por alcaldes y alguaciles inspirado en el gobierno municipal castellano y un conjunto de cargos religiosos (alféreces,

6 Powers, Karen: Andean Journeys. Migration, Ethnogenesis, and the State in Colonial Quito, University of New Mexico Press, Albuquerque, 1995, pág. 151. (Traducción nuestra).

7 Salomon, Frank: "Ancestor Cults and Resistance to the State in Arequipa, ca. 1748-1754", en Stern, Steve (editor): Resistance, Rebellion, and Consciousness in the Andean Peasant World, 18th to 20th Centuries, University of Wisconsin Press, Madison, 1987, págs. 148-165. 
mayordomos, priostes, etc.) vinculados a las festividades de los santos patrones, Corpus Christi, Semana Santa y otros momentos del calendario litúrgico cristiano. Desde un punto de vista formal, estos puestos eran rotatorios y electivos, a diferencia de los señores andinos hereditarios; en términos de las relaciones de poder concretas, los curas doctrineros, los corregidores y los vecinos de los pueblos rurales pudieron ejercer una influencia más o menos directa sobre los alcaldes y alguaciles, quienes a su vez tenían cierto poder de policía sobre sus pares. De todas maneras, la evidencia histórica sugiere que ni los cabildos ni las cofradías constituyeron sistemas de poder independientes de los caciques o, menos aún, entidades sociales independientes de los ayllus. Los servicios en las fiestas, aunque no parecen haber conllevado autoridad política alguna, se convirtieron en una de las responsabilidades de los individuos hacia la comunidad y, por ende, en un mecanismo de reafirmación de pertenencia al ayllu y de acceso a sus recursos económicos. Pero lo hicieron al lado de otras obligaciones como el tributo y la mita. Del mismo modo, si bien estos cargos civiles y religiosos aparejaban cierto prestigio social y sirvieron como medio de justificar aspiraciones al cacicazgo, también lo hicieron puestos tales como capitán de la mita, hilacata y segunda persona. ${ }^{8}$ Por otra parte, la jurisdicción de los alcaldes, cualquiera que fuera lo dispuesto en la legislación colonial, nunca pareció extenderse a cuestiones económicas vitales, como la repartición de parcelas a los miembros de la comunidad, la recaudación de las tasas o la elección de mitayos. Por ejemplo, el análisis de los intensos conflictos agrarios entre familias, ayllus y parcialidades del grupo Pocoata durante el siglo XVIII pone de manifiesto que, contra lo establecido en las ordenanzas toledanas, no eran los alcaldes sino los caciques e hilacatas quienes intervenían en este tipo de litigios. ${ }^{9}$

La subordinación de este sistema rotativo de cargos a la estructura de los grupos étnicos es en gran parte el producto de la distinta articulación de las entidades administrativas españolas con las organizaciones políticas nativas. La historiografía ha insistido, con razón, en que las variadas jurisdicciones coloniales a las que los indios quedaron sujetos

8 Un ejemplo de ello en ANB, TI, 1772, 98, ff. 78-82.

9 Serulnikov, Sergio: "Conflictos agrarios y políticos intra-étnicos en el norte de Potosí (el caso de Pocoata, siglo XVIII)", Revista Andina, 17, Cusco, 2000, págs. 65-99. Respecto de la jurisdicción de los alcaldes sobre cuestiones de tierras, véase Spalding, Karen: Huarochirí: An Andean Society under Inca and Spanish Rule, Stanford University Press, Stanford, 1984, pág. 216. 
combinaban concepciones andinas y europeas. ${ }^{10}$ Como hemos ya sugerido, los repartimientos de la provincia de Chayanta reconocían la organización vertical andina puesto que no denotaban necesariamente jurisdicciones territoriales continuas. Una aldea edificada siguiendo los patrones castellanos (o pueblo de reducción) servía como capital de los repartimientos, pero sus miembros estaban esparcidos en zonas distantes. Esto significa que los padrones coloniales incorporaban a los habitantes de los distritos de valle dentro de sus comunidades de puna respetando la división interna en ayllus menores y parcialidades. Este mismo criterio se sigue en los repartimientos compuestos por varios grupos étnicos: los hogares campesinos pertenecientes a repartimientos como Aymaya o Chayanta eran empadronados en sus comunidades respectivas, ya fuera que habitaran las tierras altas o los valles de Micani, Carasi y San Pedro de Buena Vista. Cada grupo étnico, a través de sus caciques, era responsable por la entrega de su correspondiente cuota anual de tributos y trabajadores mitayos. De manera que aunque los repartimientos pudieron ser inicialmente concebidos como unidades fiscales mínimas, no funcionaron así en la práctica ya que el estado reconocía la autonomía política y fiscal de aquellas comunidades indígenas incluidas en repartimientos multiétnicos.

En contraste con la autoridad conferida a los caciques bajo el régimen de repartimiento, la jurisdicción de los curas doctrineros y los Cabildos indígenas, estaba en esencia dictada por criterios residenciales, no étnicos. No existía así un párroco del grupo Pocoata o de sus parcialidades y ayllus componentes sino párrocos de la doctrinas de Pocoata, Micani y Carasi. En términos prácticos, la imposición de este modelo europeo de territorialidad dio lugar a que la feligresía de los curatos de valle tendiera a agrupar a comunidades diversas y los curatos de puna a sólo una sección de los gru-

10 Para el caso de Chayanta en el siglo XVIII, véase Adrián, Mónica: "Reformas borbónicas y políticas locales. Las doctrinas de Chayanta durante la segunda mitad del siglo XVIII", Revista del Instituto de Derecho, 23, Buenos Aires, 1995, págs. 97-117; "Los curatos en la provincia de Chayanta durante la segunda mitad del siglo XVIII", Data, 6, 1996; "Identidad andina y doctrinas de aborígenes en la comunidad de Chayanta a fines del XVIII", Cuaderno de Trabajo No 2, Universidad Nacional de Luján. 1997; Penry, Elizabeth: Transformations in Indigenous Authority and Identity in Resettlement Towns of Colonial Charcas (Alto Peru), Ph.D. dissertation, University of Miami, 1996; Platt, Tristan: "The Andean Soldiers of Christ. Confraternity Organization, the Mass of the Sun and Regenerative Warfare in Rural Potosi (18th-20h Centuries)", Journal de la Société des Americanistes, LXXIII, París, 1987; Serulnikov, Sergio: Subverting Colonial Authority, Spanish Rule and Andean Communities in Eighteenth-Century Southern Peru, Duke University Press, Durham, 2003. 
pos étnicos. ${ }^{11}$ La divergencia entre curato y comunidad se manifiesta en que la división de varias doctrinas (Macha/Chayrapata, San Marcos/Surumi y Pocoata/Chayala), ocurrida durante el siglo XVIII en respuesta al crecimiento demográfico y a nuevas medidas de control social no pareció afectar, como ha observado Mónica Adrián, las "relaciones étnicas" entre las familias de puna y valle. ${ }^{12}$ La erección de nuevas doctrinas no implicaba la conformación de nuevas entidades políticas ni respondía a demandas comunales de autonomía, como fue el caso de numerosos conflictos rurales en México entre sujetos y cabeceras; esta política sólo acarreaba nuevas cargas económicas para las comunidades existentes y, por consiguiente, tendió a ser vigorosamente resistida por los indios, como los machas demostrarían durante la sublevación de 1780-1781 respecto de la creación de una doctrina independiente en el distrito de puna de Chayrapata. ${ }^{13}$ En síntesis, los caciques podrían haber sido sustituidos por autoridades de carácter municipal sólo de mediar cambios drásticos en los tradicionales patrones de ocupación discontinua del espacio de las comunidades y en los modos de distribución de los recursos agrarios y las obligaciones económicas entre sus miembros. ${ }^{14}$ Los padrones de la población indígena, la documentación judicial y otras fuentes de información etnohistórica, tanto para los siglos coloniales como republicanos, señalan empero que las familias norpotosinas continuaron derivando sus derechos de posesión de la tierra e

11 Nótese que éste no fue siempre el caso. El pueblo de puna de Espíritu Santo de Chayanta, por ejemplo, no se corresponde con este patrón ya que estaba dividido en dos doctrinas, Laymi (incluía a los grupos Laymi, Puraca y Chullpa) y Chayantaca (incluía a Chayantaca, Sicoya y Caracha). Aunque estas mitades son a veces designadas "parcialidades" en los documentos de la época, no existían, como hemos mencionado, caciques a este nivel.

12 Adrián: "Identidad andina...", págs. 84-85.

13 Por ejemplo, en febrero de 1781, en pleno desarrollo de la rebelión, los machas, luego de golpear duramente a un teniente de cura de la nueva doctrina de Chayrapata, le advirtieron que no regresara al pueblo "porque no querían que este fuese curato separado del de Macha" [Archivo General de la Nación de Buenos Aires (AGN), IX, Interior, Leg. 11, Exp. 6, ff. 3-4]. Nicolás Katari, uno de los líderes de la rebelión, quien residía en Chayrapata, pidió reiteradamente la reunificación de ambos curatos. Serulnikov: Subverting Colonial Authority..., cap. 6). Véase asimismo, Adrián: "Identidad andina...", págs. 88-89.

14 Para un interpretación de este tipo, véase Penry: Transformations in Indigenous Authority... La autora sostiene que desde mediados del siglo XVIII se produce en Chayanta una paulatina fusión de la autoridad civil y religiosa bajo el sistema de fiesta-cargo, lo cual habría estado asociado a la emergencia de nuevas organizaciones políticas y, presumiblemente, al abandono de las tradicionales formas de verticalidad. Penry argumenta, por ejemplo, que "It was in the valley land such as Carasi, Micani, or Chayala that parishes of mixed 'ethnicities' were forming towns increasingly independent of any cacicazgo" (p. 290); "These [ethnic] rivalries were 'ethnic' only in the sense that the doctrina/town had come to be the primary source of identification and in that manner, an "ethnic group"" (p. 349). 
identidad social de su afiliación étnica, no de su pertenencia a los pueblos o doctrinas de indios. ${ }^{15}$

Debe notarse que en el contexto de la provincia de Chayanta fueron las jurisdicciones eclesiásticas las que en buena medida se adecuaron a las realidades sociales andinas. Así, la extendida práctica del "doble domicilio" hizo que las familias de puna sirvieran como pasantes de fiestas en las iglesias de valle de acuerdo al ritmo anual de migraciones. Una doctrina de valle como San Marcos de Miraflores, habitada por varios ayllus de Macha y algunas familias de Pocoata y Condocondo, tenía hacia fines de la década de 1770 una población permanente de 1.400 personas pero durante la época invernal de cosechas de granos ésta se elevaba a 7.000 personas. ${ }^{16}$ Los indios de puna celebraban los festivales de las doctrinas mientras cultivaban sus tierras de valle. Sabemos, asimismo, que los curas enviaban a sus asistentes a otras parroquias siguiendo los patrones migratorios de sus feligreses: dado que los indios no se ajustaban a las jurisdicciones territoriales continuas, los representantes de estas jurisdicciones comenzaron a migrar junto con sus sujetos. ${ }^{17}$ Igualmente significativo, la observancia del ciclo de festivales católicos estaba sometida a las mismas mediaciones institucionales que el resto de las exacciones coloniales. Cada grupo (en caso de doctrinas multiétnicas) y ayllu designaba sus propios alféreces, mayordomos y asistentes de las iglesias; para cumplir con el oneroso costo en dinero y productos de estos servicios, los indios recibían a su vez asignaciones especiales de tierras y prestaciones laborales de parte de sus respectivas comunidades. ${ }^{18}$ Del mismo modo, estos cargos formaban parte de un sistema inclusivo de responsabilidades rotativas ya que podían ser contabilizados a cuenta de los turnos en la mita minera y conllevaban la excepción temporal del pago de tributo. ${ }^{19}$ Cuando considera-

15 Sobre la estructuración étnica de Chayanta en el siglo XIX, véase Platt: Estado boliviano..., cap. 2; y "The Andean Experience of Bolivian Liberalism, 1825-1900: Roots of Rebellion in 19thCentury Chayanta (Potosí)”, en Stern (ed.): Resistance, Rebellion..., págs. 287-292.

16 ANB, EC, 1779, 23, f. 20. Sobre esta zona, véase Platt: "The Andean Soldiers...".

17 Adrián: "Reformas borbónicas...", pág. 32. La autora sostiene que la jurisdicción de las doctrinas era en rigor sobre personas, no territorios, y que por tanto los curatos, lejos de debilitar o disolver las identidades étnicas tradicionales, contribuyeron a consolidarlas (pag. 85).

18 Véase, por ejemplo, los testimonios de los curas del pueblo de Chayanta en ANB, EC, 1772, 120 , ff. 55 y $76-78$.

19 En la década de 1790, el intendente de Potosí explicó que los indios servían como alféreces "a cuenta de la mita": Cangiano, María Cecilia, "Curas, caciques y comunidades en el Alto Perú: Chayanta a fines del siglo XVIII", Documento de Trabajo, Jujuy, 1987, pág. 30. El estudio de Cangiano presenta ejemplos de este sistema. El cura de la doctrina de Chayanta también señaló en 1771 este fenómeno (ANB, EC, 1772, 120, ff. 76-78). 
mos la interrelación entre las fiestas religiosas y las cuestiones de tierra, tributo y mita, no sorprende entonces que fueran los caciques (autoridades de puna en caso de las doctrinas de valle) quienes estuvieran a cargo de la designación de alféreces y mayordomos. En 1770, por ejemplo, los segundas personas de los grupos Pocoata, Macha y Laymi residentes en el valle de Carasi explicaron que "por costumbre que ellos tienen esperan la venida de sus gobernadores, que esta es regularmente por San Juan [en junio], y cada gobernador juntándose con su segunda y su gente elegían los alféreces que tocan a sus respectivo aillo, de suerte que muchas veces ignora el cura quienes son los alféreces y sólo llega a saberlo el mismo día de la fiesta". ${ }^{20}$ En su estudio comparativo sobre las fiestas en el norte de Potosí a fines de los siglos XVIII y XX, Tristan Platt ha concluido que las identidades étnicas no deberían ser subsumidas en las cofradías rurales, puesto que éstas "estuvieron reorganizadas de manera tal de tomar en cuenta las migraciones estacionales andinas y las formas étnicas de complementariedad ecológica... es claro que para el siglo XVIII la reproducción social del sistema [de cofradías] había quedado enteramente en las manos de los ayllus, quienes lo han mantenido -con importantes modificacioneshasta la actualidad". ${ }^{21}$

Cuando se compara la situación de Chayanta con otras provincias del Alto y Bajo Perú advertimos que mientras la relación entre los jefes andinos y las jerarquías paralelas de autoridad tiende a presentar características análogas, al menos hasta el estallido de la insurrección tupamarista, existieron marcadas discrepancias en los alcances y la legitimidad del poder caciquil. En el caso de la región de La Paz, las formaciones precolombinas habían ya experimentado tras la conquista española un proceso más agudo de disgregación que en Chayanta. Los grupos que conformaban los señoríos del Collao, con notorias variaciones de grado y ritmo, fueron abandonando la ocupación de tierras en zonas distantes y gravitando hacia comunidades nucleadas con territorios contiguos. En provincias como Pacajes, Omasuyos, Sicasica o Chucuito, las comunidades quedaron agrupadas en lo que se ha definido como "confederaciones de ayllus" encabezados por

20 Declaración de Bartolomé Carabajal (Macha/Anansaya), Nicolas Carajurí (Macha/ Urinsaya), Nicolás Quispe (Pocoata/Anansaya), Pascual Flores (Pocoata/Urinsaya) y Julián Condo (Laymi), Octubre de 1770 (ANB, EC, 1772, 120, ff. 16-17). Sobre la intervención de los caciques de puna de Macha en asuntos de las doctrinas de valle de San Marcos de Miraflores y Surumi, véase ANB, Sublevación General de Indios (SGI), 1782, 10.

21 Platt: “The Andean Soldiers...”, pág. 168. (Traducción nuestra). Véase también, Adrián, "Reformas borbónicas...". 
caciques regionales hereditarios. ${ }^{22}$ Durante el siglo XVIII, este proceso de división territorial se profundizó aún más conforme los ayllus locales comenzaron a impugnar su subordinación a los jefes de aquellas unidades sociales mayores. Sinclair Thomson ha notado, empero, que los masivos cuestionamientos a los caciques en ese siglo no procuraron ampliar el poder de alcaldes, alféreces o mayordomos sino el poder de las tradicionales autoridades comunales, especialmente hilacatas, principales y ancianos. Los cargos en las fiestas católicas no constituyeron un factor determinante de legitimidad política puesto que, al menos hasta fines de la colonia, no existió fusión de la autoridad civil y religiosa basada en la institución de la doctrina. ${ }^{23}$ Los modelos de democracia comunal que se manifiestan antes y durante la sublevación liderada por Túpac Katari no se originaron pues en las elecciones municipales, las cuales eran formales y estaban en general controladas por los poderes rurales (incluyendo los caciques), sino en los acostumbrados principios de representación de los ayllus locales. ${ }^{24}$

En el caso de la provincia de Porco, Roger Rasnake ha mostrado que hacia la década de 1750 los ayllus de Yura y de otras comunidades fueron perdiendo sus vínculos con sus enclaves ecológicos y dejaron de identificarse como Wisijsas, un señorío aymara que había formado parte de la confederación Karakara. Las comunidades mantuvieron su estructuración en ayllus y parcialidades, pero las identidades étnicas comenzaron a circunscribirse a las jurisdicciones de los pueblos de reducción. Aún así, los jefes comunales locales que emergieron en este proceso tenían las mismas características y atributos, si no la misma extensión territorial y prestigio, que los caciques previos. ${ }^{25}$ Rasnake observa que, miradas en el largo plazo, las

22 Klein, Herbert: Haciendas and Ayllus. Rural Society in the Bolivian Andes in the Eighteenth and Nineteenth Centuries, Stanford University Press, Stanford, 1993, págs. 58-60. Un análisis comparativo de los niveles de fragmentación étnica y territorial experimentados por el Collao y Charcas en Saignes”Lobos y ovejas...”, págs. 122-124. Una comparación de ambas regiones en la actualidad en Carter, William y Xavier Albó: "La comunidad Aymara: un mini-estado en conflicto", en Albó (ed.): Raíces de América..., págs. 456-458.

23 Thomson, Sinclair: We Alone Will Rule. Native Andean Politics in the Age of Insurgency, The University of Wisconsin Press, Madison, 2002, pág. 62. Existía en cambio "un sistema de cargos comunal" que conducía a la condición de "principal". Este servía como contrapeso (o eventualmente alternativa) a los poderes establecidos — los cacicazgos y las autoridades civiles y religiosas. Las figuras centrales en este proceso fueron los hilacatas, quienes carecían de autoridad fuera de sus ayllus locales y representaron "the enduring, irreplaceable representatives of the community's base", págs. 47-48.

24 Según el autor, las cofradías y cabildos "estaban estructuradas en términos de la perdurable dinámica de los ayllus locales". Los caciques tenían un rol dominante tanto en la elección de los miembros del cabildo como de los pasantes de fiestas: Thomson: We Alone Will Rule..., págs. 51-63 y 262-268).

25 Rasnake, Roger: Domination and Cultural Resistance. Authority and Power Among an Andean People, Duke University Press, Durham., 1988, págs. 135-136. 
reformas toledanas terminaron por erosionar las identidades étnicas precolombinas pero fracasaron tanto en su intento de reasentar a la población en pueblos de reducción como en imponer un sistema de gobierno municipal alternativo a los señores andinos puesto que los miembros del Cabildo indígena "se encontraron eventualmente bajo el dominio de las autoridades hereditarias tradicionales". ${ }^{26}$ Thomas Abercrombie encuentra un proceso similar de fragmentación territorial para las comunidades de Condocondo, Culta y Challapata, pertenecientes a los grupos prehispánicos de Quillacas y Asanaques, en la vecina provincia de Paria. Aquí, sin embargo, la autoridad política dentro de las comunidades sí se fue gradualmente transfiriendo en el curso del siglo XVIII de manos de los caciques al "sistema de fiesta-cargo". Es este doble proceso de "fusión y fisión" de las antiguas formaciones sociales andinas y de emergencia de un nuevo régimen de gobierno comunal el que estaría en la base de la revuelta de los indios de Condocondo contra sus caciques hereditarios en 1774 y el subsiguiente levantamiento general de los pueblos de la provincia en 1780-1781.27

En gran parte de los Andes peruanos los alcaldes y los integrantes de las cofradías no parecen haber asumido las funciones económicas y políticas de los caciques al menos hasta la década de 1780. En un pionero estudio sobre las cofradías en la región del valle de Mantaro, Olinda Celestino y Albert Meyers plantearon tres importantes hipótesis: (1) el régimen de fiestas del calendario cristiano, en particular tras las campañas de extirpación de idolatrías del siglo XVII, constituyó un importante "refugio cultural de la región andina"; (2) el acceso rotativo a los distintos cargos de las cofradías y el Cabildo indígena permitió a los comuneros participar en las esferas de prestigio, lo cual atenuó las desigualdades sociales dentro de la comunidad y estableció un modelo de autoridad alternativo al de los caciques hereditarios; (3) los ayllus se fueron incorporando a las cofradías rurales y si bien en principio conservaron su independencia, se siguió "una lenta pero inexorable disolución porque las cofradías ganarán su unidad y poco a poco los ayllus,

26 Rasnake: Domination and Cultural Resistance..., pág. 101.

27 Abercrombie, Thomas: Pathways of Memory and Power. Ethnography and History Among an Andean People, The University of Wisconsin Press, Madison, 1998, págs. 251-258. Véase asimismo, Penry: Transformations in Indigenous Authority..., págs. 25-146. Para un análisis comparativo del proceso de conformación de Yura, Culta y Chipaya (un enclave Uru en una zona predominantemente aymara) en el siglo XVIII y de la aplicación de la categoría de etnicidad a estas formaciones sociales, véase Wachtel, Nathan: "Note sur le problème des identités collectives dans les Andes méridionales", L'Homme, 122-124, Paris, 1992. Para un balance de esta problemática, véase Larson, Brooke: Colonialism and Agrarian Transformation in Bolivia. Cochabamba, 1550-1900, Duke University Press, Durham, 1997, págs. 353-359. 
que la componen, ya ni serán mencionados."28 Mientras aspectos de las primeras hipótesis han sido en general corroborados para toda el área andina, varias de las posteriores investigaciones sobre el Bajo Perú tienden a indicar que la disolución de los ayllus y la decadencia de los caciques es un proceso que no parece delinearse al menos hasta el período colonial tardío o - como señala Pablo Macera en la misma introducción al volumen de Celestino y Meyers respecto de la persistencia del ayllu como unidad social básicahasta bien entrado el siglo XIX. ${ }^{29}$ En efecto, si bien los ritmos y causas del declive de los caciques al norte del Lago Titicaca presentan amplias variaciones regionales, los estudios monográficos muestran que en numerosas comunidades indígenas de Canas y Canchis, Quisquipanchis, Azangaro, Jauja, Huarochirí y Lambayeque, en la costa norte, los descendientes de antiguos linajes nobles conservaron el control de la mayoría de los cacicazgos nativos hasta fines de la colonia. ${ }^{30}$ En ciertas áreas conservaron asimismo considerable legitimidad: los trabajos de Ward Stavig sobre la zona del Cuzco comprueban que, en marcada contraposición con el Alto Perú, durante el siglo XVIII se gestaron escasas protestas colectivas y litigios contra los señores andinos; aún durante el levantamiento tupamarista mismo, pese al total colapso de las instituciones locales de gobierno, los indios tendieron a acatar la decisión de sus jefes étnicos, ya fuera para respaldar u oponerse a aquel. ${ }^{31}$

28 Celestino, Olinda y Meyers, Albert: Las Cofradías en el Perú: región central, Verlag Klaus Dieter Vervuert, Frankfurt, 1981, págs. 90, 110, y 106, respectivamente. Los autores concluyen que las cofradías muestran "el rol de la religión católica durante la colonia, en la etnogénesis del futuro indio andino. Los indígenas, a partir de la instalación colonial española, pertenecían, en ese orden, a su familia, a su cofradía y a su comunidad, y en algunos casos a su hacienda" (pág. 131).

29 Celestino y Meyers: Las Cofradías en el Perú..., "Presentación" de Pablo Macera, págs. 11-12. Recientemente, Charles Walker ha sostenido que las comunidades indígenas en el Cuzco no perdieron su vitalidad hasta mediados del siglo XIX, Walker, Charles: Smoldering Ashes. Cuzco and the Creation of Republican Peru, 1780-1840, Duke University Press, Durham, 1999.

30 O'Phelan Godoy, Scarlett: Kurakas sin sucesiones. Del cacique al alcalde de indios (Perú y Bolivia 1750-1835), Cuzco, Centro de Estudios Regionales Andinos Bartolomé de las Casas, 1988, págs. 22-24; Flores Galindo, Alberto: Buscando a un Inca: identidad y utopía en los Andes, Instituto de Apoyo Agrario, Lima, 1987, pág. 136-138; Jacobsen, Nils: Mirages of Transition. The Peruvian Altiplano, 1780-1930, University of California Press, Berkeley, 1993, págs. 82-84. Sobre la costa norte, véase Rostworowski de Diez Canseco, María: Curacas y sucesiones. Costa Norte, Minerva, Lima, 1961, págs. 54-57. Sobre el poder y prestigio conservado por la elite incaica en los alrededores Cuzco durante el siglo XVIII, véase Garret, David: "Los incas borbónicos: la elite indígena en vísperas de Túpac Amaru", Revista Andina, 36, Cusco 2003, págs.9-63.

31 Stavig, Ward: The World of Túpac Amaru. Conflict, Community, and Identity in Colonial Peru, University de Nebraska Press, Lincoln, 1999, pág. 229-233. Este fenómeno se trasladó en parte a la época post-Túpac Amaru. El trabajo de Charles Walker para la región de Cuzco muestra que las protestas contra los caciques durante la era colonial tardía fueron menos marcadas en el caso de los caciques hereditarios que en el de los nuevos caciques recaudadores Walker: Smoldering Ashes..., págs. 75-77. 
Para la región de Huarochirí, Karen Spalding ha notado que "la nobleza indígena a nivel provincial mostraba en 1750 considerable renuencia a involucrarse en la estructura de gobierno civil y religioso, en contraste con la tendencia en el siglo XVI... Estos cargos [civiles y religiosos] se habían tornado esencialmente en posiciones de servidumbre bajo el control de curas y corregidores, y la elite indígena se replegó a ejercer la autoridad que todavía podía detentar dentro de la comunidad local al margen de la estructura de gobierno colonial". ${ }^{2}$

Esta situación se iba a transformar de manera drástica tras la revolución de Túpac Amaru. La decadencia de los jefes étnicos no fue empero un proceso meramente gradual, evolutivo, orgánico: remite a la rápida y completa disolución de lo que habían sido hasta entonces las bases económicas, simbólicas y políticas de su poder. Como es bien conocido, luego de la insurrección general el estado colonial abolió los cacicazgos rebeldes, eliminó todos los privilegios de la nobleza indígena que estaban asociados al pasado incaico y puso fin a la jurisdicción de los caciques sobre la cobranza de los tributos (la cual constituía un mecanismo primordial de acceso a los recursos agrarios y servicios laborales de la comunidad) en favor de nuevos "caciques recaudadores". ${ }^{33}$ Es en este nuevo contexto que los llamados alcaldes varayoks comenzaron a representar una alternativa efectiva a la institución caciquil. La tenaz resistencia campesina a los "caciques recaudadores", quienes eran mestizos o criollos nombrados directamente por los subdelegados, la pérdida de poder de los tradicionales señores andinos y la defensa de los criterios consensuales y electivos representados por los varayocs jugaron un papel crucial en este proceso. ${ }^{34}$ Por otro lado, los

32 Spalding: Huarochirí..., pág. 237. (Traducción mía).

33 Un ejemplo del indisoluble vínculo entre recaudación tributaria y autoridad caciquil en el contexto de la provincia de Chayanta emergió en 1771, cuando un cacique propietario del grupo Caracha, Alejandro Yavira y Ayaviri, fue despojado de su jurisdicción sobre la cobranza de las tasas. Aunque las autoridades coloniales argumentaron que, en tanto cacique propietario, éste debía continuar recibiendo de parte de los indios "los emolumentos, honores y preeminencias", el padre del Yavira y Ayaviri explicó que al ser separado de la recaudación tributaria, "se ha dado margen a que los Indios no le den aquella obediencia y subordinación que corresponde a su empleo, de forma de que el día de hoy sólo tiene el título de Cacique en cuanto al nombre pero en sustancia se halla privado de todos aquellos salarios, servicios y vasallajes que deben tener y gozar... respecto de que todos los ingresos que obtenían de tierras y chacras se les han aplicado al dho. cobrador Calli como asimismo el salario..." (ANB, TI, 1772, 14, ff. 4-5)

34 Hünefeldt, Christine: Lucha por la tierra y protesta indígena: las comunidades indígenas del Perú entre colonia y república, Bonner Americanische Studien, Bonn, 1982, págs. 27-28; O'Phelan Godoy: Kurakas sin sucesiones..., págs. 41-52; Sala i Vila, Núria, Y se armó el tole tole. Tributos indígenas y movimientos sociales en el virreinato del Perú, 1784-1814, IER, Cusco, 1996, págs. 65-97; para el caso de Cuzco, véase, Walker: Smoldering Ashes..., cap. 2; sobre Huaylas-Ancash, véase Thurner, 
cambios en el sistema de autoridad parecen corresponderse, como habían postulado Celestino y Meyers, con trasformaciones en la propia naturaleza de la comunidad rural. En su estudio sobre el área de Puno a fines de la colonia y comienzos del siglo XIX, Christine Hünefeldt sostiene que el ascenso de los alcaldes supuso "una exigencia modernizante que partía de la comunidad, que luego de pasar por la desestructuración de los tradicionales lazos étnicos tendió a agrupar horizontalmente a los comuneros..." 35 Del mismo modo, Nuria Sala i Vila señala que, dado que los caciques contribuían a consolidar un tipo de poblamiento discontinuo "por el control de diversos pisos ecológicos y por dispersión mitmae", mientras los alcaldes "venían a resolver las necesidades de administración de asentamientos de tipo hispano, reducciones o pueblos, que disolvían y redefinían las formas sociales de los aborígenes", el ascenso de los últimos fue un proceso "democratizador a la vez que disgregador" ${ }^{66}$ Se trata entonces de la reconstitución de las comunidades rurales bajo principios más contractuales e individualistas. Es interesante apuntar que esta interpretación se comparece con observaciones similares para ciertas regiones del Alto Perú, como los valles de Cochabamba y Larecaja, donde las comunidades indígenas coloniales surgieron de la agrupación de mitimaes pertenecientes a diferentes grupos prehispánicos y donde las haciendas se expandieron con relativa rapidez. Las fiestas y cofradías sirvieron aquí como mecanismos fundamentales de integración de indios forasteros y mestizos y de consolidación de un sentido colectivo de comunidad. Al igual que lo sucedido en el Bajo Perú desde fines del siglo XVIII y en el curso del siglo XIX, el rol pivotal de este tipo de instituciones remite al desarrollo de una sociabilidad menos fundada en el parentesco, más "voluntarista", propia de comunidades con un mayor nivel de fragmentación étnica y cultural. ${ }^{37}$

\footnotetext{
Mark: From Two Republics to One Divided. Contradictions of Postcolonial Nation-Making in Peru, Duke University Press, Durham, 1997, págs. 35-44; sobre Arequipa, véase Manrique, Nelson, Colonialismo y pobreza campesina. Caylloma y el valle de Colca, S. XVI-XX, DESCO, Lima, 1986, págs. 172-177; sobre el valle de Jauja, Burga, Manuel: "El Perú Central, 1770-1860", Revista peruana de ciencias sociales, vol 1, n. 1, Lima, 1987; sobre Azángaro, Jacobsen: Mirages of Transition, pág. 97. Según O'Phelan Godoy, el sistema de elección de los caciques se fue asimilando para esta época al del Cabildo indígena, O’Phelan Godoy : Kurakas sin sucesiones..., pag. 39.

35 Hünefeldt: Lucha por la tierra..., págs. 34-35.

36 Sala i Vila: Y se armó..., pag. 162.

37 Larson: Colonialism and Agrarian Transformation..., págs. 352-358; Saignes: "Lobos y ovejas...", págs. 122-124; e "Indian Migration and Social Change in Seventeenth-Century Charcas", en Brooke Larson and Olivia Harris with Enrique Tandeter, eds.: Ethnicity, Markets, and Migration in the Andes, Duke University Press, Durham, 1995, págs. 186-189.
} 
$\mathrm{Si}$, como ha sugerido Nathan Wachtel, las identidades colectivas en los Andes meridionales comenzaron a configurarse para esta época en función de una base territorial común, la organización dualista, representaciones simbólicas fundamentadas en un sincretismo pagano-cristiano y la expresión institucional de este sincretismo, los cargos civiles y religiosos, parece claro, regresando ahora al caso de la provincia de Chayanta, que estas identidades no pasaron a inscribirse aquí en el marco local. ${ }^{38}$ Sin embargo, el hecho de que durante las décadas previas a la gran rebelión de 1780-1781 los indios no hayan demandado o imaginado el reemplazo de los cacicazgos por un sistema basado en criterios residenciales, no significa que las formaciones políticas norpotosinas estuvieran completamente cristalizadas. Los movimientos, no obstante, parecen haber seguido una dirección opuesta a la atomización observada en otras áreas del Alto Perú: estuvieron orientados hacia la fusión en vez de la división de las comunidades, al menos a nivel de las jefaturas étnicas; fueron promovidos por los funcionarios coloniales y/o por ciertos caciques; y fueron firmemente resistidos por los indios del común. Tal es el caso, por ejemplo, de la unificación en la década de 1760 de los cacicazgos de Puraca y Laymi (repartimiento de Chayanta) bajo el mando de un cacique de este último grupo llamado Marcos Soto. Aunque esta medida puede ser atribuida a las vinculaciones entre ambas comunidades en un censo de 1683 Puraca todavía figuraba como uno de los ayllus menores de Laymi- ${ }^{39}$, éstas constituían para mediados del siglo XVIII dos entidades independientes con sus respectivas autoridades. Las recurrentes protestas de los puracas contra sus jefes étnicos durante las décadas de 1740 y 1750 sugieren que la supresión de su autonomía política no fue un desarrollo espontáneo sino un intento por parte de los funcionarios coloniales de restablecer el orden social. ${ }^{40}$ Es significativo al respecto que Marcos Soto fuera uno de los primeros caciques arrestados por los indios insurrectos en septiembre de 1780; luego de la rebelión, y durante el siglo XIX, Puraca aparece de nuevo como una comunidad independiente. ${ }^{41}$ Otro proceso de

38 Wachtel: "Note sur le problème...".

39 AGN, Sala XIII, 18-7-3. Olivia Harris ha notado que los territorios de puna de Laymi y Puraca se encuentran actualmente entremezclados, mientras que los otros grupos del antiguo repartimiento colonial mantienen una clara autonomía espacial y social Harris, Olivia: "From Asymmetry to Triangle: Symbolic Transformation in Northern Potosí”, en Murra, John, Wachtel, Nathan y Revel: Jacques (editores) Anthropological History of Andean Polities, Cambridge, University Press, Cambridge, 1996, págs. 262-263.

40 Vease Serulnikov: Subverting Colonial Authority..., cap. 1.

41 Véase el padrón de 1786, en AGN, XIII, 18-10-3; y Cangiano: "Curas, caciques...," pág. 35. Sobre Laymi y Puraca en el siglo XIX, véase Platt: “The Andean Experience...,, págs. 288 y 308. 
fusión, aunque de diferentes características, emergió también hacia mediados de la década de 1760 en el pueblo de Moscari, cuando su cacique, Florencio Lupa, procuró obtener el cambio de adscripción étnica de una centena de familias campesinas pertenecientes a varias comunidades de las provincias de Chayanta y Paria que arrendaban tierras en las haciendas de este distrito. Tampoco en este caso el proyecto fue del todo arbitrario puesto que Moscari era un pueblo originado luego de la conquista española como resultado de la agrupación de indios pertenecientes a diversas comunidades. El emprendimiento puede ser visto entonces como la continuación de un proceso de etnogénesis, un proceso de readscripción étnica colectiva. $\mathrm{La}$ iniciativa, en cualquier caso, ponía en cuestión los tradicionales principios andinos de verticalidad y desafiaba una estrategia clave de adaptación indígena a las demandas coloniales puesto que los arrendatarios continuaban pagando sus tributos en sus pueblos de origen aunque sus nombres no figuraban en los padrones coloniales. La oposición a este proyecto, finalmente abortado, no se hizo esperar: el corregidor de la provincia dijo haber recibido el reclamo de varios de los caciques para continuar recaudando los tributos de estas familias campesinas, así como "la exclamación que muchos de [los indios arrendatarios] me hicieron deseando siempre reconocer su origen". ${ }^{42}$

En 1772, este mismo cacique de Moscari fue designado como cacique de los grupos Pocoata y Panacachi. En contraste con Laymi y Puraca, no existían vínculos sociales que pudiera justificar la unificación de estas comunidades bajo el mismo gobierno. De hecho, tanto el corregidor como la Audiencia de Charcas justificaron la expansión del poder de Florencio Lupa exclusivamente en términos de disciplinamiento social. ${ }^{43}$ La creación de un cacicazgo multiétnico suscitó durante los años 1775-1778 un proceso de agitación rural sin precedentes en la provincia, el cual concluyó con la recuperación de la autonomía política de los indios de Pocoata y Panacachi. En particular, las masivas movilizaciones de los originarios y forasteros de los diez ayllus de Pocoata ofrecieron un modelo directo de lucha para las protestas de sus vecinos de Macha que harían eclosión en la

42 AGN, Sala XIII, 18-9-5. "Autos obrados por Juan Francisco Navarro, Corregidor de Chayanta", Véase también Adrián:, "Los curatos...", págs. 106-107; y Serulnikov: Subverting Colonial Authority..., cap. 2.

43 Véanse testimonios del corregidor y la Audiencia en AGN, IX, Interior, Leg. 4, Exp. 7. Lupa fue designado oficialmente "cobrador de tributos" de Pocoata y Panacachi pero, como los pocoatas dejarían en claro, esto implicaba lisa y llanamente la asunción del cacicazgo (sobre este tema, cf. nota 33). 
insurrección general de $1780 .{ }^{44}$ Considerando sus ominosas consecuencias, no extraña que los funcionarios coloniales hayan decidido abandonar este tipo de políticas: cuando en 1784 un cacique de Auquimarca reclamó ser nombrado como cacique de Cayanas (ambos grupos pertenecientes al repartimiento de valle de San Pedro de Buena Vista), el subdelegado de Chayanta y la audiencia rechazaron de plano el pedido argumentando, "de notoriedad ser distintas las citadas Parcialidades, a semejanza de otras que encierran los demás pueblos, y como tales fueron gobernadas por dos caciques las de San Pedro..." ${ }^{45}$ En definitiva, como hemos anotado arriba, la estructuración étnica de la provincia de Chayanta se iba a trasladar sin alteraciones sustanciales al período republicano.

Ahora bien, es preciso subrayar que la ausencia de los procesos de fragmentación territorial, o de aquellas tendencias "disgregadoras" o "modernizantes" que han sido observadas en otras comunidades indígenas en las postrimerías de la dominación española, no significa en absoluto la ausencia de reclamos "democratizadores". Por el contrario, fue esta clase de demandas de democratización política las que sirvieron de plataforma para la más radical insurrección campesina ocurrida en el norte de Potosí durante los tiempos coloniales. Sólo que este fenómeno no parece obedecer aquí a ninguno de los tres modelos explicativos que dan cuenta de la crisis de los cacicazgos en el resto del espacio andino: la defensa de los derechos políticos de la aristocracia indígena frente a la agresiva intromisión de los corregidores en las estructuras de poder nativas; la resistencia de los ayllus locales a los caciques de las unidades mayores a las que estaban integrados; la competencia entre las autoridades étnicas tradicionales y el sistema de cargos civiles y religiosos de los pueblos de reducción. Para comprender la dinámica de este proceso en Chayanta hay que hacer una clara distinción entre la institución caciquil y la legitimidad de los caciques. La siguiente sección aborda esta temática.

\section{Autoridad étnica y legitimidad política}

Si una de las características distintivas de las jefaturas étnicas norpotosinas fue su continua centralidad en la organización social de las comu-

44 Sobre este proceso, véase Penry: Tansformations in Indigenous Authority..., págs. 286-309; Serulnikov, Sergio: "Customs and Rules: Social Conflicts in the Age of Bourbon Reformism (Northern Potosi in the 1770s)", Colonial Latin American Review, 8, New York, 1999.

45 ANB, SGI, 1784, 63, f. 61. Nótese que la expresión "pueblos" se refiere aquí los pueblos de reducción y "parcialidades" a los grupos étnicos. 
nidades, un segundo fenómeno de importancia no menos decisiva fue la decadencia de los cacicazgos hereditarios. Al igual que en la mayor parte del sur andino, la designación por parte de los corregidores de caciques interinos capaces de facilitar los repartos forzosos de mercancías llevó a una gradual disminución del número de caciques propietarios. En contraste con la región del Cuzco, para el siglo XVIII la mayoría de los caciques ya no pertenecía a linajes nobles. Pero lo que es más significativo todavía, aquellos caciques que aún provenían de antiguas familias de señores andinos, lejos de simbolizar la memoria histórica y la autonomía política de la comunidad, eran los más integrados a las estructuras de poder colonial. Siglos de relaciones de parentesco, alianzas comerciales e interacción social con los vecinos españoles y criollos de los pueblos rurales tornó a las elites indígenas en mestizos y hacendados asimilados a los grupos hispanos. A diferencia de lo ocurrido en el siglo XVII, por ejemplo, con los prósperos caciques del pueblo de Jesús de Machaca, José y Gabriel Fernández Guarachi, los indios del común no parecieron considerar que sus autoridades emplearan estos recursos económicos y culturales en defensa de los intereses colectivos ${ }^{46}$ En Chayanta, señores andinos tradicionales como los Ayaviri Cuisara de Sacaca, Ayra Chinchi de Pocoata o Florencio Lupa de Moscari estuvieron entre los principales blancos de las protestas campesinas. ${ }^{47} \mathrm{La}$ afirmación de Scarlett O'Phelan Godoy respecto de que "sería más conveniente hablar de la presencia de dos ramas paralelas de caciques, una legítima, de linaje, y otra ilegítima impuesta por el corregidor" parece tener validez para vastas zonas del Bajo Perú; en la mayor parte del distrito de la Audiencia de Charcas, los cuestionamientos a los caciques hereditarios provinieron de ambos extremos de la sociedad rural. ${ }^{48}$

Este proceso trajo aparejada una trasformación fundamental en las nociones indígenas de autoridad. El descrédito de la aristocracia nativa se trasladó al principio mismo sobre el que se fundaba su poder: los indios dejaron de considerar los derechos de sangre como fundamento suficiente

46 Sobre los Fernández Guarachi, véase Rivera Cusicanqui: "El mallku...”; y Saignes... "De la borrachera", pág. 147-148.

47 Sobre los Ayaviri Cuisara y los Ayra Chinchi, véase Arze, Silvia y Ximena Mendinaceli: Imágenes y presagios. El escudo de los Ayaviri, Mallkus de Charcas, HISBOL, La Paz, 1991; Saignes: "De la borrachera...”, págs. 147-8 y 157; Del Rio: "Estructuración étnica...”, pág. 17; Platt: "Mapas coloniales...”, págs. 104-11; Serulnikov: "Conflictos agrarios”, págs. 89-90. Sobre Lupa, véase, Penry: Tansformations in Indigenous Authority..., págs. 148-218; y Serulnikov, Subverting Colonial Authority..., cap. 2.

48 La cita en O’Phelan Godoy: Kurakas sin sucesiones..., pág. 21. 
(o necesario) de la autoridad caciquil. ${ }^{49}$ A diferencia de la "fiebre por títulos y genealogías que se apoderó de la elite indígena" en otras regiones de los Andes, como respuesta a las agresivas políticas de los funcionarios provinciales, los líderes de las protestas en el norte de Potosí no plantearon el conflicto en términos de sus superiores derechos de sangre. ${ }^{50}$ Parece evidente, en mi opinión, que así como la práctica de designar caciques intrusos sirvió en el corto plazo los intereses económicos de los corregidores, en el largo plazo contribuyó a despojar la institución caciquil de las connotaciones aristocráticas que los "señores naturales" habían asumido tras la conquista europea. No fueron estos principios nobiliarios sino ideas de representación las que informaron los cuestionamientos a los caciques vigentes, tanto aquellos designados por los corregidores como de aquellos con derechos hereditarios. Frente a los criterios de control social esgrimidos por los funcionarios provinciales para justificar la designación arbitraria de caciques interinos, ciertos grupos indígenas plantearon sus reclamos en términos de su supuesto consenso (los denunciantes eran "aclamados" por la comunidad y los caciques vigentes eran considerados "despóticos") y sus supuestos servicios a la Corona (denuncias de usurpación tributaria). Por cierto, la postulación de criterios consensuales no presupone la existencia práctica de consenso. Este argumento fue esgrimido en disputas más o menos facciosas encabezadas por sectores desplazados de las elites indígenas (una serie de conflictos por el control del cacicazgo de Chullpa a fines de la década de 1740 es un ejemplo de ello), así como en rebeliones de gran escala como las protagonizadas por pocoatas y machas desde mediados de los años setenta. ${ }^{51}$ Para los propósitos de este artículo, baste enfatizar, empero, que el principio que en todos los casos hace inteligible la acción colectiva es que los indios no se consideraban obligados a obedecer a autoridades étnicas que no los representaran, cualquiera fuese la fuente de su poder. En suma, para el siglo XVIII la institución cacical continuó jugando un rol primordial en el funcionamiento de la sociedad norpotosina —un rol más crítico aún conforme se agudizaba la presión sobre las tierras, las cargas fiscales y el reparto de mercancías-, al mismo tiempo que su legi-

49 Sobre la crisis de los caciques hereditarios en el Alto Perú, véase Rasnake: Domination and Cultural Resístanse...; Thomson: We Alone Will Rule...; Abercrombie: Pathways of Memory...; Penry: Transformations in Indigenous Authority....

50 O'Phelan Godoy: Kurakas sin sucesiones..., pag. 19.

51 Sobre los conflictos en el grupo Chullpa, véase Serulnikov, Sergio: "De forasteros a hilacatas: una familia andina del grupo Chullpa, provincia de Chayanta, siglo XVIII", Jahrbuch fur Geschichte Lateinamerikas, 40, Colonia, 2003, (en prensa). 
timidad dejó de estar sometida a rígidos principios nobiliarios. El control de las jefaturas étnicas se transformó así en el objeto de luchas entre criterios de disciplinamiento y criterios de representatividad.

Algunos ejemplos tomados de los conflictos sociales que afloraron en la provincia de Chayanta desde mediados del siglo XVIII nos permitirán apreciar esta dinámica. Entre fines de las décadas de 1740 y comienzos de la de 1760 se produjeron generalizadas confrontaciones entre indios y elites rurales por el control de los cacicazgos de varios grupos étnicos. En uno de estas disputas, los miembros de Jukumani ignoraron la autoridad de su cacique, Juan de Dios Umacaya, y entregaron los tributos a un indio a quien ellos mismos habían elegido en su reemplazo. Se dijo que con el objeto de apaciguar los reclamos, Umacaya había convocado al líder rebelde para designarlo como su cobrador, pero éste había aducido "que vería primero si la gente de su ayllo lo quería por su Principal Cobrador, y que con las resultas pasaría a ver a dho. su gobernador". ${ }^{22}$ Los jukumanis no sólo entregarían los tributos a este indio sin autorización alguna del cacique, sino que luego exigirían su destitución. En marzo de 1750, el corregidor provincial se lamentó que el nuevo cacique "ha venido a enterarme en presencia de muchos Indios sin ningún título de cobrador ni recaudador de dichas tasas ni otra particular intendencia mía ni de dicho gobernador [Umacaya]" ${ }^{53}$ El cabecilla del movimiento en Puraca, uno de los principales focos de protesta, nunca expuso sus derechos hereditarios; sostuvo en cambio que había sido designado cacique "a pedimiento [sic] de la comunidad." ${ }^{4}$ En el caso del grupo Chullpa, el único de los participantes en las protestas que dijo pertenecer a un linaje noble renunció a hacer valer el "notorio derecho que a este empleo tengo por ser hijo primero del último poseedor que lo fue legítimo por derecho de sangre" en favor de otros cabecillas del movimiento. ${ }^{55}$ Reflejando acaso el carácter democratizador de estos reclamos, la riqueza personal, al igual que el linaje, tampoco aparecen como un atributo de legitimidad política. Las promesas de mayor eficacia en la recaudación tributaria que se empleaban para justificar el reemplazo de los caciques vigentes se basaron menos en la solvencia económica individual - como fue el caso, por ejemplo, en una prolongada disputa de este tipo ocurrida en Tapacarí, Cochabamba, para esta misma época-que

52 ANB, EC, 1750, 20, Gaspar Cayo ante Aoíz, marzo de 1750.

53 ANB, EC, 1750, 20, Auto del corregidor Aoíz, marzo de 1750.

54 ANB, EC, 1750, 60, Sebastián Auca a Tomás de Landaeta, marzo de 1750.

55 ANB, EC, 1772, 58. 
en la presentación de detalladas listas que probaban la inexactitud de los padrones oficiales. ${ }^{56}$

Como ya hemos mencionado, los ayllus de Pocoata llevaron a cabo masivos reclamos y demostraciones de fuerza contra la designación del cacique de Moscari en reemplazo de sus propios caciques, los descendientes de un linaje noble del pueblo llamados Ayra Chinchi. Sin embargo, una vez obtenida la remoción de Florencio Lupa en 1776, impidieron la restitución de sus anteriores jefes étnicos. Forzaron en cambio el nombramiento de los dos indios que habían encabezado el levantamiento en ambas parcialidades del pueblo. Los pocoatas de Urinsaya argumentaron que si bien sólo los Ayras Chinchi poseían derechos de sangre, el nuevo cacique los trataba "con amor y desinterés que no se ha experimentado con otros caciques por lo que se ha mantenido el pueblo... sin las revoluciones e inquietudes que suelen ocasionar los caciques". ${ }^{57}$ Poco después, durante las etapas iniciales de la rebelión general norpotosina, también los indios de Macha reclamaron la sustitución de sus autoridades étnicas por el líder de la protesta, Tomás Katari, un indio del común cuya aspiración al cacicazgo no se fundó en su supuesta pertenencia a un linaje noble. ${ }^{58}$ Apenas estallado el levantamiento, virtualmente todas las comunidades de la provincia (una de las pocas excepciones fue Pocoata) procedieron a perseguir, arrestar y, en el caso de Moscari, ajusticiar a sus respectivos caciques. Entre éstos se encontraban los de Sacaca, los Ayaviri Cuisara; pese (o más bien debido) a que pertenecían a una de las más antiguas familia de señores andinos, al pedir el reemplazo de los Ayaviri por nuevas autoridades propuestas por los indios, Tomás Katari reclamó que se "quiten todos los gobernadores españoles y mestizos que en el día ejercen los empleos de caciques principales, que así se conseguirá la paz, el mayor servicio de V. M. Católica y aumento de sus Reales Intereses". ${ }^{59}$ Marcos Soto, el mencionado cacique de Laymi y Puraca, fue también llevado por la fuerza al pueblo de Macha. Se dijo que éste "dentró al gobierno pobre Indio Col-

56 Sobre Tapacarí, véase Larson: Colonialism and Agrarian..., págs. 159-167. Los indios de Puraca y Chullpa exhibieron, entre 1747 y 1750, al menos cuatro listas de tributarios ante la audiencia, algunas de las cuales incluían estancias, ayllus menores y el numero de indios integrantes del cabildo y las cofradías (ver ANB, EC, 1750, 20; ANB, EC, 1750, 60; y ANB, EC, 1772, 58).

57 AGN, Sala IX, Interior, Leg. 9, Exp. 2, ff. 11-14.

58 En 1759 un Andrés Katari aparece como uno de los cinco caciques de Macha, pero no en Majapicha, el ayllu al que pertenecía Tomás (ANB, TI, 1774, 252). Este nunca mencionó a Andrés como su pariente. Fuera de estas vagas alusiones a su "derecho de sangre", el cual no fue avalado por documento alguno, su aspiración al cacicazgo se fundó siempre en el consenso de la comunidad.

59 AGN, IX, Interior, Leg. 8, Exp. 1, ff. 65-66. 
cheado como cualquiera otro Indio desdichado y ahora tiene más caudal que otro cualquiera caballero de comercio". ${ }^{60}$ La demanda de que Soto fuera destituido ilustra también el tipo de nociones representativas, contractuales detrás de estas iniciativas: los laymis sostuvieron ante Katari que "ahora decimos que ya no lo queremos por Gobernador por lo que experimentamos tantos maltratamientos y trabajos, sino que se nos nombre otro gobernador a quien la comunidad eligiese que sea de nuestra clase". ${ }^{61}$

Un contra-ejemplo de esta forma de concebir la autoridad étnica nos puede ayudar a resaltar su novedoso carácter. En octubre de 1780, en pleno desarrollo de la sublevación, un indio del grupo Panacachi llamado Asencio Isidro Sicara Florgain viajó a Buenos Aires para reclamar ante el virrey, como Tomás Katari lo había hecho dos años antes, la deposición de su cacique. En contraposición con aquel, sin embargo, Sicara Florgain exhibió documentos de 1696 y 1705 que acreditaban sus derechos hereditarios y recordó que las ordenanzas establecían que los caciques debían "suceder[se] de unos en otros sólo por derecho de sangre", una proposición que ninguno de los indios rebeldes defendió. ${ }^{62}$ Estas opuestas representaciones ideológicas guardan una indudable relación con las opciones políticas: Sicara Florgain no procuró el respaldo de Katari para obtener la destitución de su cacique, como lo hicieron el resto de los indígenas; por el contrario, sabemos que un miembro de Panacachi llamado Sicara se contó entre los integrantes de la aristocracia nativa que durante el levantamiento campesino buscaron refugio en la Iglesia del pueblo de San Pedro de Buena Vista.

¿Cuáles son los orígenes de estas ideas representativas, igualitarias, de autoridad caciquil? Sin pretender dar una respuesta exhaustiva, es claro que los problemas de legitimidad política y los de reproducción social estuvieron estrechamente entrelazados. Los conflictos entre comunidades y caciques desde mediados del siglo XVIII hasta el estallido de la rebelión general evidencian el vínculo entre las nociones de autoridad y la racionalidad económica de los ayllus. La vinculación entre economía y política, no obstante, estuvo lejos de ser lineal. Por un lado, resulta evidente que las acusaciones contra los jefes étnicos remiten a un conjunto de cuestiones materiales críticas en la vida de la sociedad andina. Entre éstas se destacan la administración de predios y molinos de granos comunales; la defensa de

60 AGN, IX, Interior, Leg. 8, Exp. 1, ff. 8-10.

61 Ibídem.

62 AGN, IX, Interior, Leg. 8, Exp. 17. 
los territorios étnicos en las disputas limítrofes con haciendas y comunidades aledañas; el abastecimiento, status tributario y criterios de elección de los mitayos; la usurpación de las tasas mediante el sub-registro de indios tributarios; la apropiación del dinero de la comunidad depositado en la Caja de Censos; la participación en el reparto de mercancías de los corregidores; y el uso de la fuerza laboral en emprendimientos comerciales propios o en asociación con sectores hispanos. Por otra parte, sin embargo, sería incorrecto atribuir la creciente agitación rural a las prácticas caciquiles mismas, muchas de las cuales constituían establecidas estrategias de adaptación y resistencia a las exacciones coloniales. Es significativo al respecto que los caciques no denegaran a menudo la existencia de los "abusos" que los indios les imputaban: argumentaron que se trataba simplemente de arraigadas costumbres y que éstas eran indispensables para afrontar sus obligaciones hacia la comunidad y el estado. ${ }^{63}$ Así pues, al justificar el uso de las rentas de dos haciendas y molinos de granos de la comunidad, el cacique de Moscari explicó en 1760 que el dinero era destinado, entre otras erogaciones, a provisiones de coca y aguardientes durante tres listas de mitayos "para con aquel esfuerzo obligarlos [a los indios] a que vayan, como mis antecesores lo acostumbraron"; a gastos de transporte durante la entrega de los tributos; al pago de las tasas de los mitayos que "según costumbre inmemorial dejan de pagar tres tercios de tributos"; y a la cancelación de deudas de tasas y repartimientos de mercancías, "cuyas dependencias si se pierden son de mi cuenta" ${ }^{64}$ También el cacique de Chullpa, al dar cuenta del empleo de los fondos de la Caja de Censos y del arrendamiento de unos predios que el grupo poseía en el paraje de Bombo, observó en 1761 que,

"son notorios los gastos que necesariamente me ocasiona el Oficio de Cobrador que obtengo en las Cabalgaduras que mantengo para las caminatas, en el amanuense que asalariado traigo siempre en mi compañía y en el de aguardiente, chicha y coca con que es costumbre de tiempo inmemorial complacer y festejar a los indios anualmente al tiempo de la recepción de los dhos. reales tributos.” ${ }^{65}$

63 Para un análisis de la apelación a las "costumbres" en los litigios entre indios y caciques y la relación entre prácticas económicas y legitimidad política en el siglo XVIII en la región de La Paz, véase Thomson: We Alone Will Rule..., págs. 82-105.

64 ANB, TI, 1773, 34, ff. 45-47.

65 ANB, TI, 1761, 30, Martin Ninavia a la audiencia, abril de 1761. También el cacique de Puraca exhibió en 1757 una detallada lista de los gastos que debía afrontar como parte de las reglas de reciprocidad ("convites" durante las celebraciones colectivas y asistencia a los mitayos) y de las obligaciones hacia la Iglesia y los corregidores provinciales (ANB, Minas, tomo 127, No XIV, 1757-58, No 1153). 
En rigor, tampoco los indígenas negaron que el cargo acarreara crecidas responsabilidades económicas y, al menos tácitamente, que muchas de las actividades que ellos denunciaban fueran imprescindibles. Los chullpas, quienes tuvieron la oportunidad de responder directamente a las afirmaciones de su cacique, confirmaron que éste tenía la obligación de distribuir considerables cantidades de coca, chicha y aguardiente durante celebraciones tales como la Pascua o la partida de los mitayos a Potosí. Lo que refutaron es que estos "convites" hubieran sido costeados por el cacique; era la comunidad en su conjunto, mediante su trabajo y sus recursos agrarios, la que los solventaba. Resumiendo su visión de las relaciones económicas entre ayllu y cacique, los chullpas sostuvieron que,

"no sale de su caudal cosa alguna [en las celebraciones], porque en lugar de dar avío a los cédulas les manda hacer chicha y compra coca vendiendo los frutos de las sementeras que siembran todos los indios con sus propios bueyes y rejas y sus personas con nombre de común. Con que viene a salir a costa de los mismos indios porque ellos lo trabajan, y como la cosecha la coge el Gobernador le da el nombre de propio desembolso, que si llegaran a tomarse cuentas en el asunto saliera alcanzado porque los gastos en dichos obsequios no pasan de veinte cantaros de chicha y valen a cuatro reales dos cestos de coca y una o dos arrobas de aguardiente que lo más se consume entre los Gobernadores y sus principales; y que en las mulas no gasta cosa alguna porque los indios le siembran cebada hasta ponérsela en su casa, como sucede con las sementeras de maíz, papas y trigo en los mejores parajes de las tierras del común, de modo que el Gobernador después de mantenerse de dichas cosechas y costear los dichos dos convites le queda aún para vender sin que le haya costado un maravedí, más que mandarlo con rigor y tener el trabajo de guardar la semilla para el año siguiente." ${ }^{66}$

Este testimonio sugiere que el problema no radicaba en que los emprendimientos de los caciques sirvieran exclusivamente para su enriquecimiento personal o, menos aún, de una oposición tajante entre modelos de comportamiento económico mercantiles y no-mercantiles. A semejanza de los innumerables alegatos de este tipo producidos desde mediados de siglo hasta el levantamiento general de 1780, el texto presenta dos niveles posibles de lectura. Reflejando en parte la lógica del discurso judicial español, parece denunciar la existencia misma del trabajo colectivo en las tierras comunales, la falta de renumeración salarial y, en general, el intercambio asimétrico de bienes y servicios que tiene lugar entre los indios y el caci-

66 ANB, EC, 1762, 63. Santos Vias, Manuel Mamani y Ramos Halaro ante Tadeo Chacón, marzo de 1762 . 
que. Por detrás de esta lógica, se puede percibir otra clase de racionalidad propia de las sociedades andinas: la descripción de las prácticas caciquiles no conlleva un repudio de las prácticas sino de los caciques a cargo de implementarlas. En la primera lectura, es la naturaleza de las actividades económicas lo que torna despótica la autoridad de los caciques; en la segunda, es la naturaleza de la autoridad de los caciques lo que torna despóticas sus actividades económicas. En otras palabras, el punto fundamental que emerge de esta extraordinaria descripción de la economía moral del ayllu andino es que el cacique era considerado un mero administrador de los bienes producidos por la fuerza de trabajo, tierras y ganados de la comunidad. Su acceso a este conjunto de recursos era el resultado, en última instancia, de una delegación de responsabilidades. La riqueza no la originaba el cacique ni era su propiedad, la producía la comunidad y era, por consiguiente, su patrimonio. La generosidad constituía un deber, no una gracia. Lo que estaba en disputa entonces eran menos las prácticas mismas que el significado social implícito en los intercambios materiales y simbólicos entre caciques y comunidades ("[c]on que viene a salir a costa de los mismos indios porque ellos lo trabajan, y como la cosecha la coge el Gobernador le da el nombre de propio desembolso"). Tanto la redistribución como las actividades que permitían solventarla - la comercialización de los excedentes agrarios comunales, el ocultamiento de tributarios, el arrendamiento de molinos y tierras comunales - no pueden ser comprendidas fuera de lógica cultural que les daba sentido. ${ }^{67}$ La legitimidad de las autoridades andinas, en fin, determinaba la percepción de sus comportamientos económicos, no menos que éstos su legitimidad.

Podríamos argumentar, por tanto, como se ha afirmado con respecto al campesinado francés en el siglo XVIII, que la creciente agitación social contra los jefes étnicos -el principal detonante de la violencia colectiva durantes estos años- no fue tanto la consecuencia de cambios en el peso o en la naturaleza de las exacciones económicas, como de su pérdida, percibida o real, de utilidad. En el caso de Francia, las cargas señoriales comenzaron a ser vistas como "injustas y detestables" a medida que el estado absolutista fue absorbiendo algunas de las formas de protección a los campesinos que habían estado tradicionalmente a cargo de la nobleza rural. ${ }^{68}$ De manera

67 Stern, Steve:, "The Variety and Ambiguity of Native Andean Intervention in European Colonial Markets", en Larson, Harris, Tandeter: Ethnicity, Markets..., págs. 73-99. Cf. asimismo nota 1. 68 Markoff, John: The Abolition of Feudalism. Peasants, Lords, and the Legislators in the French Revolution, The Pennsylvania State University Press, University Park, 1996, págs. 18-19. 
similar, conforme la intensificación de las presiones económicas (agrarias, fiscales, demográficas, mercantiles) y los prolongados procesos de diferenciación interna (económica, cultural, en los estilos de vida y patrones de interacción con las elites rurales) erosionaron la percepción de los señores andinos como salvaguardas del bienestar de la comunidad, sus fuentes de ingresos y demandas materiales empezaron a aparecer como arbitrarias e injustificadas. ${ }^{69}$ Parafraseando una interpretación acerca de los motivos de la profundización de las tensiones sociales durante las décadas previas a la Revolución Francesa, el descontento rural tenía menos que ver con una cuestión de gravámenes que con una cuestión de justicia. ${ }^{70}$

Es en este punto donde se puede apreciar con nitidez la conexión entre las emergentes concepciones de autoridad étnica y la función social de los caciques norpotosinos. Las prolongadas y extendidas protestas que surgen desde mediados de siglo, y que crean el clima para la sublevación general de 1780, estuvieron dirigidas a cerrar la brecha entre la racionalidad económica y la racionalidad política de las estructuras andinas de gobierno. Puesto que, en contraste con otras regiones altoperuanas, las identidades colectivas no experimentaron durante esta época modificaciones sustanciales, y los caciques continuaron jugando un rol crítico en el funcionamiento de la organización segmentaria, el patrón disperso de residencia y la verticalidad económica, la institución caciquil misma no fue impugnada. Pero dado que el uso del dinero, el trabajo y los excedentes agrícolas comunales debía estar sujeto a una serie de normas redistributivas consuetudinarias, y dado que durante el siglo XVIII el acceso al cargo estaba en la práctica cada vez más desligado de criterios nobiliarios y los descendientes de los antiguos "señores naturales" dejaron de ser vistos como los defensores del interés general, la legitimidad de los caciques comenzó a fundarse exclusivamente en la calidad de su gestión. La reciprocidad económica que debía regir su relación con los miembros de los ayllus empezó de hecho a corresponderse con un principio contractual de legitimidad política por el cual las comunidades (o ciertos grupos en el seno de las mismas) se abrogaron el derecho de exigir su remoción, y la designación de sus reemplazantes, de acuerdo a su presunta capacidad o incapacidad para cumplir con sus responsabilidades hacia los indios y el estado. Si el desdeño por los derechos hereditarios de los señores

69 Acerca de las tensiones económicas en la sociedad rural andina durante el siglo XVIII, véase Larson: Colonialism and Agrarian...; y Tandeter, Enrique: "Población y economía en los Andes (siglo XVIII)", Revista Andina, 13, Cusco, 1995.

70 Markoff: The Abolition of Feudalism..., pág. 18. 
andinos sirvió a los corregidores como mecanismo de control sobre los campesinos andinos, también sirvió a éstos como un medio de afirmar la naturaleza reversible, representativa de la autoridad caciquil.

\section{Cambios y continuidades}

Los estudios antropológicos han demostrado que el norte de Potosí es una de las zonas de Bolivia donde la estructura del ayllu andino ha demostrado una mayor capacidad de pervivencia histórica. A pesar de sucesivos intentos de los gobiernos republicanos por privatizar la propiedad rural y abolir jurídicamente la comunidad indígena, algunos grupos étnicos han preservado su tradicional organización segmentaria y dual y continúan controlando terrenos discontinuos en punas y valles. Un complejo sistema de autoridades está a cargo de distribuir predios a los miembros del pueblo, organizar los ciclos productivos y recaudar la tasa, una contribución que, aunque ha ido perdiendo toda significación económica, conserva un importante valor simbólico como medio de legitimar el acceso a los recursos comunales. Las autoridades étnicas ejercen en muchos casos control sobre familias que residen en zonas ecológicas distantes, aunque a diferencia de sus predecesores coloniales, estas autoridades son en la actualidad electivas y rotativas. ${ }^{71}$ No se trata, desde luego, de subestimar las profundas mutaciones sociales y culturales ocurridas como resultado, entre otros fenómenos, de los sucesivos programas liberales y populistas de reforma agraria, la apertura de los mercados regionales al comercio internacional, la expansión de las haciendas, las migraciones, el desarrollo de nuevos centros mineros o los intentos de sustituir a las autoridades étnicas por organizaciones sindicales subordinadas al estado. Considerando la magnitud de estas fuerzas históricas, lo que debiera llamar nuestra atención es que los modos fundamenta-

71 Sobre las funciones de las autoridades étnicas, véase Rivera Cusicanqui, Silvia: Ayllus y Proyectos de desarrollo en el norte de Potosí, Ediciones Aruwiyri, La Paz, 1992, págs. 113-122. Los estudios etnográficos sobre el norte de Potosí incluyen Godoy, Ricardo: Mining and Agriculture in Highland Bolivia: Ecology, History, and Commerce Among the Jukumanis, The University of Arizona Press, Tucson, 1990; Harris, Olivia: "From Asymmetry to Triangle"; y To Make the Earth Bear Fruit: Ethnographic Essays on Fertility, Work and Gender in Highland Bolivia, Institute of Latin American Studies, London, 2000; Pacheco Balanza, Diego y Guerrero Peñaranda, Edgar: Machas, Tinkipayas y Yamparas, Provincia Chayanta (Norte Potosí), CIPRES, Sucre, 1994; Platt, Tristan: "El rol de ayllu andino en la reproducción del régimen mercantil simple en el norte de Potosí (Bolivia)", en Briggs, Llanque Chana, et.al.: Identidades andinas y lógicas del campesinado, Mosca Azul Editores, Lima, 1982, págs. 25-83; y "Mirrors and Maize: The Concept of 'Yanatin' among the Macha of Bolivia”, en Murra, John, Wachtel, Nathan y Revel, Jacques (editores): Anthropological History of Andean Polities, Cambridge, University Press, Cambridge, 1996, págs 228-259. 
les de reciprocidad y propiedad colectiva de los recursos agrarios no se hubieran desvanecido por completo. Precisamente esto es lo que sucedió en buena parte de los Andes bolivianos y peruanos, donde desde las postrimerías del período colonial se experimentó un proceso gradual de fragmentación política, reducción o desaparición de los territorios comunales, eliminación de las tradicionales formas de gobierno y abandono de los mecanismos de cooperación económica e identidad étnica.

Creemos que la historia de la región durante el período colonial tardío ofrece ciertas claves para comprender algunos de los orígenes de este fenómeno. Hemos anotado en la primera parte de este trabajo una serie de factores que parecieron favorecer la reproducción de las formaciones políticas norpotosinas que emergieron tras la disolución de las grandes confederaciones aymaras: los mecanismos institucionalizados e informales de adaptación de las unidades administrativas y eclesiásticas coloniales a las realidades sociales andinas; la ausencia de una tendencia más o menos espontánea hacia el abandono de los lazos entre los habitantes de las punas y los valles; la firme, y en general exitosa, resistencia colectiva a la pérdida de las autonomías étnicas. También la estructura y los criterios de legitimidad de los cacicazgos discutidos aquí aparecen reflejados en la ulterior evolución de estas comunidades rurales. Aunque carecemos de estudios detallados sobre la provincia de Chayanta luego de la sublevación general, sabemos que el sistema de los cacicazgos no sufrió modificaciones fundamentales. Muchos de los caciques que sobrevivieron a los ataques indígenas, o sus descendientes, recuperaron el control de las jefaturas étnicas. Incluso algunos de los indios rebeldes que tuvieron una participación prominente en los eventos de 1780-1781 pudieron retomar su lugar en la comunidad debido a su rol en la captura de los hermanos Katari y otros líderes indígenas. Es indudable, en todo caso, que ni el estado colonial ni los campesinos andinos exhibieron el tipo de determinación de eliminar los cacicazgos que se manifiesta en el Bajo Perú. Así pues, cuando a fines de la década de 1790 los funcionarios españoles intentaron establecer una nueva mita minera volvemos a encontrar a los caciques, junto a otros miembros de la sociedad nativa, negociando una vez más el lugar de los ayllus en el orden colonial. ${ }^{72}$

72 Sobre el rol de los caciques y segundas personas en esta disputa, véase Adrián, Mónica: "Doctrinas y feligreses en la punas de Chayanta", Historia y Cultura, 24, La Paz, 1997, págs. 149-163; Arze Aguirre, Rene: Participación popular en la independencia de Bolivia, Oraganización de los Estado Americanos, La Paz, 1979, págs. 64-66 y 97-99; Buechler, Rose Marie: The Mining Society of Potosí, 1776-1810, Syracuse University Press, Syracuse, 1981; Cangiano: "Curas, caciques...". 
Por debajo de estas continuidades, empero, tanto las nuevas maneras de concebir la legitimidad caciquil que emergen durante el siglo XVIII como el fracaso de proyectos políticos basados en aquellos principios representativos pudieron dejar su marca en las posteriores transformaciones del gobierno comunal. Por un lado, los procesos de diferenciación social entre caciques e indios que en buena medida habían llevado a la insurrección de 1780-1781 parecieron profundizarse aún más luego de su derrota. En particular tras la abolición de los cacicazgos establecida por el nuevo gobierno republicano en 1825, el cargo de cacique — no así los cargos a nivel de los ayllus menores - pasó a manos de "recaudadores". Aunque, en contraste con otras áreas de los Andes, la integridad territorial de los antiguos grupos étnicos no sufrió alteraciones significativas y estas nuevas autoridades continuaron ejerciendo un poder similar al de los antiguos caciques -mantuvieron por ejemplo el usufructo de los servicios laborales en las tierras del común y ejerciendo autoridad sobre familias residentes en punas y valles-, los recaudadores eran por lo general comerciantes, hacendados y mineros criollos o mestizos ajenos por completo a las comunidades. No debe sorprender, entonces, que las ideas representativas de gobierno que vimos irrumpir en el último siglo colonial también reaparecieran con fuerza en este contexto. Desde mediados del siglo XIX, en el curso de prolongadas luchas entre el estado boliviano y los pueblos rurales respecto de la naturaleza de los servicios laborales indígenas, el reemplazo del tributo por un impuesto individual y los proyectos liberales de privatización de las tierras comunales, los campesinos norpotosinos abrogaron de manera sistemática por la preservación del sistema tradicional de autoridades comunales (no su abolición o fragmentación) pero bajo principios radicalmente distintos a los vigentes para entonces: como sus antepasados en 1780, los indios reclamaron que las autoridades fueran de su misma "clase" ("raza" era la nueva terminología de los tiempos) y gozaran del consenso de los ayllus. ${ }^{73} \mathrm{Al}$ igual que en el caso del levantamiento general de fines del siglo XVIII, la absoluta centralidad de estas demandas iba a quedar de manifiesto en la mayor conmoción social de la época, la revolución liderada por Zárate Wilka en 1899.

En el curso del siglo XX, el complejo sistema de autoridades étnicas, aunque aún regido por arraigadas formas andinas de organización social y

73 Platt: “The Andean Experience...”, pag. 313. Véase también, Platt: Estado Tributario...; e Irurozqui, Marta: "The Sound of the Pututos. Politicisation and Indigenous Rebellions in Bolivia, 18261921”, Journal of Latin American Studies, 32, London, 2000, págs. 85-114. 
verticalidad ecológica, se iría finalmente transformando en una democracia rotativa fundada en el principio de que el cargo es tanto un privilegio como una obligación hacia la comunidad. ${ }^{74} \mathrm{Si}$ bien durante el período colonial tardío los indios reclamaron jefes étnicos que fueran representativos de la comunidad, no un régimen de autoridades rotativas, es posible conjeturar que para los integrantes de los ayllus de Chayanta que desde mediados del siglo XVIII habían expresado mediante litigios judiciales y movilizaciones masivas que no había razón para tolerar caciques abusivos (fueran éstos hereditarios o designados por los corregidores), puesto que su única fuente de legitimidad derivaba de su apropiada administración del producto del trabajo campesino y su defensa de los intereses colectivos, esta evolución no debió haber parecido del todo extraña.

74 Rivera Cusicanqui: Ayllu y Proyectos..., págs. 117-122. 